\title{
„KULTURA“ I „PRIRODA“ U SLUŽBI DRŽAVE - PRIKAZ FENOMENA SOCIJALNOG DISCIPLINIRANJA NA PRIMJERU DRŽAVNE REGULACIJE ODNOSA DRUŠTVA I OKOLIŠA SLAVONSKE VOJNE KRAJINE U DRUGOJ POLOVINI 18. I POČETKOM 19. STOLJEĆA
}

\begin{abstract}
Prosvjetiteljsko doba donosi velike društvene i okolišne promjene diljem europskog kontinenta, od kojih su za hrvatski povijesni prostor među važnijima svakako bile promjene započete reformnim procesima u doba vladavine Marije Terezije i njezinih nasljednika. U ovom radu nastoje se prikazati odredeni mehanizmi državne regulacije $i$ uvodenja promjena u društvene i okolišne strukture Slavonske vojne krajine u drugoj polovini 18. i početkom 19. stoljeća na temelju fenomena socijalnog discipliniranja ranonovovjekovnog slavonskog stanovništva, koji je kao posljedicu imao i (pre)uredenje slavonskog okoliša. Pri tome se analiziraju različiti povijesni izvori i arhivska grada narativne, statisticke i administrativne provenijencije, koji se odnose na spomenuto razdoblje i prostor.
\end{abstract}

Ključne riječi: Slavonska vojna krajina, prosvijećeni apsolutizam, socijalno discipliniranje, okoliš, 18. stoljeće, 19. stoljeće

1. Prosvijećeni apsolutizam, kultura i okoliš u Slavonskoj vojnoj krajini

Prosvjetiteljska paradigma nije se ni mogla konstituirati bez binarne matrice 'priroda' „/ vs. 'kultura', odnosno, 'barbarstvo' vs. 'civilizacija'. Žanrovski vrlo različiti dokumenti suvremene kulture putovanja morali su što znalačkije i sugestivnije 'otkrivati' i 'prirodu', ali i 'detektirati' umješnost ljudskog ovladanja prirodom, tj. 'kulturu'. ".

Ovim riječima povjesničar Drago Roksandić opisuje prosvjetiteljsku paradigmu putopisaca druge polovine 18. stoljeća ${ }^{2}$ i njihovu perspektivu društva i okoliša na ovim prostorima. Spomenutu perspektivu nisu dijelili samo putopisci već i njihovi čitatelji i „mecene“, odnosno elita Habsburške Monarhije - Dvor, plemstvo i kler. Naročito je habsburškome Dvoru bio vrlo važan koncept kulture, odnosno „umješnosti ljudskog ovladanja prirodom“ i njezino značenje u metodama, ciljevima i ishodima politike prosvijećenog apsolutizma tijekom 18. i dijelom 19. stoljeća. Prosvjetiteljska politika habsburškog Dvora oko uređenja i reorganizacije društva i okoliša može se vrlo dobro promatrati na području ranonovovje-

Drago Roksandić, „Drava u očima jozefinista“, u: Ekohistorija rijeke Drave: zbornik s međunarodnog znanstvenog skupa (ur. Dragutin Feletar - Hrvoje Petrić - Drago Roksandić), Koprivnica 2011, 24-25.

2 Od prosvjetiteljskih putopisaca koji su putovali Slavonijom i ostavili svoje opise društva i okoliša svakako bi trebalo izdvojiti sljedeće: Friedrich Wilhelm von Taube (Povijesni i zemljopisni opis Kraljevine Slavonije i Vojvodstva Srijema, 1777-1778), Franz Stefan Engel (Opis Kraljevine Slavonije i Vojvodstva Srema, 1786), Matija Piller - Ljudevit Mitterpacher (Putovanje po Požeškoj županiji u Slavoniji 1782. god.). 
kovne Slavonije, koja pada pod habsburšku vlast mirom u Srijemskim Karlovcima 1699. Zbog položaja Slavonije na "fronti“ između Osmanskog Carstva i Habsburške Monarhije u prijašnjim dvama stoljećima, ona je područje izrazito slabe naseljenosti te niske razine obrađenosti i male površine agrarnog zemljišta, čijem su razvoju prijetile ratne ekspedicije i pustošenja imperijalnih vojski, ali i lokalni pljačkaški upadi i prepadi iregularnih vojnih i hajdučkih bandi, što je od strane novih vlasti zahtijevalo velika ulaganja u poljoprivrednu i upravnu infrastrukturu te "socijalno discipliniranje“ naroda. ${ }^{3}$ Slavonija, a naročito Slavonska vojna krajina, koja se nalazila pod izravnom dvorskom vojnom upravom, mogla je poslužiti kao svojevrsna tabula rasa, gdje je habsburški Dvor mogao provoditi otvorenu i gotovo neometanu politiku te "pokusirati“ na području administrativne i ekonomske politike u skladu s vlastitim idejama i interesima.

Pojam „,socijalnog discipliniranja“ se, prema riječima njemačkog povjesničara Gerharda Oestreicha, može promatrati kao „politički i društveni rezultat apsolutizma“4. lako se u 16. i 17. stoljeću fenomen socijalnog discipliniranja javlja prvenstveno koncentriran oko državne uprave, crkvenih struktura i vojske kao izvora "discipline“, u 18. stoljeću postaje široko rasprostranjen društveni fenomen, koji ne samo da se nastoji infiltrirati u svaku društvenu sferu, već širi svoj obrazac „reda“ i na prirodu, "divljinu“, nastojeći je „civilizirati“. ${ }^{5}$ Procesi "civiliziranja“ i "kulturacije", ali u smislu prirode i "kultivacije", u Europi se mogu pratiti već od srednjeg vijeka, ${ }^{6}$ no svoj vrhunac svakako postižu u doba baroka i konfesionalnih reformi 16. i 17. stoljeća, gdje pridonose stvaranju apsolutizma i koncepta "ljudskog“ i "prirodnog“ poretka, prava i hijerarhije, odnosno prvenstvu čovjeka nad prirodom. ${ }^{7}$ Prosvijećeni apsolutisti 18. stoljeća preuzimaju sličan obrazac prirodnog poretka i prava od svojih „baroknih“ prethodnika te ga proširuju istovremeno kroz sve slojeve društva i sve oblike okoliša, koristeći se pri tome metodama socijalnog discipliniranja. ${ }^{8} \mathrm{U}$ slučaju prosvijećenog apsolutizma i uprave nad slavonskim zemljama mogu se izdvojiti dvije osnovne metode: upućivanje, učenje i savjetovanje nižih slojeva stanovništva na temelju relevantnih radova i poduka ili usmjeravanje, ograničavanje i uređivanje stanovništva na osnovi zakonodavnog sustava baziranog na nadzoru i kažnjavanju.

3 Roksandić, „Posavska krajina/granica od 1718.-1739. godine“, Ekonomska i ekohistorija: časopis za gospodarsku povijest i povijest okoliša, 3, 2007, 64.

4 Gerhard Oestreich, Geist und Gestalt des frühmodernen Staates: Ausgewählte Aufsätze, Berlin 1969, 188.

5 Anette Völker-Rasor (ur.), Rani novi vijek, Zagreb 2016, 298.

6 Povijesne procese te dihotomiju pojmova „civilizacija“ i „kultura“ iz sociološke je perspektive obradio sociolog Norbert Elias u svom djelu O procesu civilizacije 1-2: sociogenetska i psihogenetska istraživanja (prev. Marijan Bobinac), Zagreb 1996, dok je te pojmove u historijskom kontekstu prosvjetiteljskog razdoblja obradio Nathaniel Wolloch, History and Nature in the Enlightenment: Praise of the Mastery of Nature in Eighteenth-Century Historical Literature, Farnham ${ }^{1} 2010$.

7 Usp. Peter Harrison, "Subduing the Earth: Genesis I, Early Modern Science, and the Exploitation of Nature", The Journal of Religion, 79/1, 1999, 86-109.

8 Više o fenomenu i tumačenju samog pojma socijalnog discipliniranja i metodama istoga u: Robert van Krieken, "Social Discipline and State Formation: Weber and Oestreich on the historical sociology of subjectivity", Amsterdams Sociologisch Tijdschrift, 17/1, 1990, 3-28; Winfried Schulze, "Gerhard Oestreichs Begriff 'Sozialdisziplinierung in der frühen Neuzeit'", Zeitschrift für historische Forschung, 14/3, 1987, 265-302. 


\section{Socijalno discipliniranje podukom, savjetom i senzibiliziranjem}

Što se tiče prve spomenute metode, svakako bi trebalo izdvojiti djelo bivšeg notara Požeške županije Ignjata (Ignatija) Jablanczyja pod nazivom Prirucsna knjiga za slavonsku seljansku mladex ucsitti u dobro naredjenom poljskomu radjenju... (tiskano u Beču 1772. godine), koja je zapravo prijevod i adaptacija djela austrijskog agronoma i dvorskog savjetnika Johanna Wieganda Handbuch für die Österreichische Landjugend: zum Unterricht einer wohlgeordneten Feldwirtschaft, izdanog godinu dana ranije, 1771. Jablanczyju je od strane Marije Terezije i Ugarske dvorske kancelarije zapovjeđeno prevesti to djelo na „ilirski“, odnosno „slavonski“ jezik kako bi se ovdašnje stanovništvo moglo učiti pravilnom poljodjelskom zanatu. Ovo je djelo napisano kao priručnik za seljake, prije svega za ratare i stočare, što i kako treba raditi u seljačkome poslu te kako paziti i održavati vlastito imanje, ${ }^{9}$ pri tome objašnjavajući i opisujući uzroke, posljedice i pojave. Jablanczy (Wiegand u originalu) dotiče se i tada nove okolišne problematike, primjerice, u poglavlju o šumama, iako ne spominje izravno slavonske šume, ali objašnjava nove okolišne fenomene i društvene problematike, poput "nestanka šuma“ u uvodnom dijelu svoga priručnika, odnosno pokušava senzibilizirati i usmjeriti čitaoce kako postupati sa šumom kao važnim društvenim, ali i državnim resursom:

Ako csovik istom bomisli, kako pocsinu dervah od dana do dana vecsma nestati, za isto odmahscje poznati, kako jest veoma potribno obcsinskom brigom nastajati, da se shumme boljma zacsuvaju i za unapridak, $i$ dothasta vrjemenah nahrane. ${ }^{10}$

Ovdje se vidi stupanj osviještenosti o stanju u šumama i potrošnji drvene građe u drugoj polovini 18. stoljeća, barem od strane pismenog i školovanog stanovništva, kojemu se pripadali Wiegand i Jablanczy, no oni su također i državni službenici koji provode politiku i volju habsburškog Dvora i nižih državnih instancija, inspirirani prosvjetiteljskim idejama toga vremena. Jablanczy se dalje bavi šumama pred kraj svojeg djela (9. poglavlje, glava treća, Kakose moraju divji shtabri nahraniti) koje se može dalje podijeliti u 4 dijela: osvještavanje o stanju šuma i zašto bi seljak trebao učiti i tog nauka, uloga lovaca (lugara) u dosadašnjem nauku o šumama, opisi različitih vrsta stabala, tla na kojima uspijevaju i savjeti o njima te naposljetku koju korist seljak ima iz toga.

a) Osvještavanje o stanju šuma i zašto bi seljak trebao učiti i tog nauka

(...) neshto mervo spomenuo; jerbo zadovolno vidimo, da darvah svaki dan vecsma nestane, i njihova cijena se sve udilj vecsma nadiže: $i$ zaradi toga za isto veoma jest vrjedno, i potribno, da se brinemo, kako bismo mogli barem za nashe, Poslidnje kakvu polashcsicu ucsiniti. Skoro svaki Texacski Gazdacsje megju svojima zemljama takva prazna mjestah naicsi, gdi brez toga damu hocsje u sjejanju njegvomu neshto

9 Vrlo sličan Kućniku, kalendarskom priručniku Josipa Stjepana Reljkovića, gdje se daju savjeti seljacima koje poslove obavljati u koje doba godine. Usp. Josip Stjepan Reljković, Kućnik (prir. Josip Bratulić), Vinkovci 1994.

10 Ignatio Jablanczy, Prirucsna knjiga za slavonsku seljansku mladex ucsitti u dobro naredjenom poljskomu radjenju..., Beč 1772, 39. 
pomanjkati: nebi mogao; pacse morao: shtabre za vatru usaditi: ali mu samo nauk, i uputjenje falli, kakobi se morao toga posla iz parvine primiti, i s' njime opraviti. ${ }^{11}$

Ovdje se naglašava prije svega mogućnost sadnje drveća za ogrjev na dijelovima zemljišta gdje seljak inače ne sije druge kulture, a kojih po mišljenju autora ima sasvim dovoljno da seljaka neće oštetiti za urod, već će mu biti od koristi za kasnije te će buduće generacije imati drveća za ogrjev, pri tome misleći najvjerojatnije na niske šume (gajeve) panjače, koje su najisplativije za eksploataciju ogrjevnog drveta. ${ }^{12}$ Pri tome kaže kako seljaku samo nauk, i uputjenje falli, odnosno zalaže se za obrazovanje i senzibiliziranje seljačkog sloja stanovništva, koji ima direktni kontakt s agrarnim proizvodnim mehanizmima.

\section{b) Uloga lovaca (lugara) u dosadašnjem nauku o šumama}

Istina jest, da oko toga posla bise morali lovci, illi tako nazvani Jagari najbolje razumiti, i njihova bila bi duxnost bila, da seljanske Ljudi naucse, i upute, kako bi valljalo za uzmloxenja darvah divje shtabre saditi: ali ovi ljudi se dosada naj vecsma s' lovinom, i okolo zvirjah zabavljashe, i malo se za shumme, i darvah brinushe: nishta ne manje uzdamse, da njihovog cesarskog kraljevskog velicsjanstva naj milostiveishija naredba, poradi ovih Jagarskih Ljudi ucsinjena, odselecjse prostima Ljudma za vecsja pomocs, i korist biti. ${ }^{13}$

Autor ovdje kritizira lovce (lugare), koji su imali dužnost i brigu općenito oko šumskih resursa, ${ }^{14}$ no tu su dužnost obavljali samo površno, mareći više za šumsku faunu nego floru. Također, autor navodi kako postoji novi carski i kraljevski zakon (vjerojatno misli na „Šumski red“ Marije Terezije koji je doživio nekoliko izmjena i dopuna 1750-ih i 1760-ih godina, ovisno o tome za koje je područje bivao donesen) ${ }^{15}$, a kojim se trebalo urediti lugarsku službu tako da bude na korist pučanstvu. Istovremeno, ne teži se samo izravnom obrazovanju i senzibiliziranju šireg sloja stanovništva za pitanja agrarne proizvodnje i nove okolišne problematike već se provodi i reforma "državnih organa", odnosno onodobnih činovnika i slojeva društva zaduženih za provedbu i nadzor svih sfera državne politike habsburškog Dvora.

\section{c) Opisi različitih vrsta stabala, tla na kojima uspijevaju i savjeti o njima}

Hrast, kao po shummi kralj hocsje u svakoi zemlji izrastiti, samo u kamenitoi i Pjeskovitoi zemlji nikakose necsje mocsi pomocsi. Ako csovik xira posadio, tako mora po onomu mjestu u parvoi, i drugoi godini ill jecsam, ill heldu posjejati: da, ako zir nikao, i izashao, mladice pod posjejanim zittom sjennu, i hlad mogu imati: tretje godine,

11 Isto, 194-195.

12 Više o razvoju šumarstva i razlikama u eksploataciji šuma kroz različite povijesne periode u: Joachim Radkau, Wood: A History (prev. Patrick Camiller), Cambridge, UK 2012.

13 Jablanczy, Prirucsna knjiga, 195.

14 Riječ je zapravo o ostatku srednjovjekovne uloge plemićkih i kraljevskih lovaca i lugara, naročito u njemačkim povijesnim zemljama. Usp. Radkau, Wood, 189-190.

15 Bogoslav Kosović, „Red i instrukcija kako se imadu u buduće upravljati i uzčuvati šume Vojne krajine u kraljevini Slavoniji, te kako se pri izvršavanju tih svojih dužnosti imadu vladati šumari, koji će se za to postaviti“, Šumarski list, 5-6, 1915. 
poslije ovoga sjejanja vecs ne potribuje; ali samo valjja veoma oshtro zabraniti, da se na takovo mjesto, gdje takvoga sada od mladih shtabarah imade; marva ni poshto ne upuschcsa, jerbocsje mladice sve popasti, i pogristi. (...) Brizovini svaka zemlja ugodi: jerbo csovik vidi, da ona u suhoi, mershavoi i kamenitoi zemlji bash onako dobro, kao u doljini, i u jarku pokraj vode naraste. Lippovina se skoro u svakomu selu nahodi; iztoga moxe seljanski csovik lasno poznati, kakve varste zemlja njoi naj boljma ugodi. ${ }^{16}$

Autor navodi vrste drveća, počevši od bjelogoričnog prema crnogoričnom. Dijeli ih po kategorijama tla na kojemu najbolje uspijevaju te također savjetuje kako se s pokojim vrstama treba ophoditi. Zanimljiv je pri tome upis za lipe, gdje navodi kako ih ima u svakome selu i zbog toga seljanski csovik može lako prepoznati koja im vrsta zemlje najbolje odgovara. Ta rečenica zapravo daje uvid u praktičnost prosvjetiteljskih težnji za reformom, odnosno da postoje dijelovi prosvjetiteljskog diskursa gdje se prepoznaje i priznaje već stečeno znanje nižih društvenih slojeva (u ovom slučaju kako seljaci već sami znaju koja vrsta tla najbolje odgovara lipi za rast). Istovremeno se uz zadržavanje "lokaliziranog znanja“, koje prosvjetiteljski reformatori smatraju korisnim, širi i svojevrsna "nadgradnja“ postojećeg znanja (npr. savjet da se uz posađeni žir u prvoj i drugoj godini posije ječam ili heljda koji bi mladici hrasta pružali potrebnu zaštitu od sunca i vjetra) ili izbacivanje „štetnog“ ponašanja, kao što je u ovom slučaju primjer zabrane puštanja stoke unutar mlade šume na ispašu, kako bi se zaštitile mladice u fazi razvoja.

\section{d) Koju korist seljak ima iz toga}

I s' takvim nacsinom biticsje seljanski csovik bash kao kakvi plemenit csovik, ili mali spahija, kada bude na svojemu sinora mekote za sjedbu; csajire: baschcse: vinograde; i shumme imao: shto sve moxe dobiti, i imati, ako bude hotio istom pomljivo, $i$ vierno raditi, i za podobriti svoje stanje $s^{\prime}$ razlogom, i naredno se brinuti. ${ }^{17}$

Ovdje autor navodi kako bi seljak, ako se drži takvih pravila oko rada i uređivanja svojih polja, pašnjaka, livada, vinograda i šuma, u budućnosti mogao uživati pogodnosti vlastitog zemljišta kao „sitni plemić“ i poboljšati svoje trenutno materijalno stanje. lako je za potrebe analize u ovom radu izabran dio oko šumske problematike, primjećuje se sličan obrazac u cijelom Jablanczyjevu djelu, gdje se nastoji uređivanjem seljačkog posjeda i organiziranjem novih agrarnih sustava proizvodnje postići društvena, ali i okolišna reforma, s naglaskom na senzibiliziranju društva za nove okolišne fenomene i probleme. U ovom se slučaju može koristiti pojam "kultura“ kao vrhunac prosvjetiteljske politike, gdje se istovremeno nastoje „kultivirati“ društvo i okoliš, odnosno društvo i okoliš bivaju izloženi tzv. " "civilizacijskim procesima“, kojima je cilj potpuna reorganizacija svih društveno-okolišnih instancija u korist "općeg dobra“, što inkluzivno označava i korist države. ${ }^{18}$

16 Jablanczy, Prirucsna knjiga, 195-196.

17 Isto, 197.

18 Više o ulozi ranonovovjekovne države u "civilizacijskim“ i "kultivacijskim“ procesima te njezinu djelovanju na društvo i okoliš usp. Völker-Rasor (ur.), Rani novi vijek, 149-150, 206, 353; Wolloch, History and Nature, 68-92. 


\section{Socijalno discipliniranje zakonskim uređenjem, ograničavanjem i kažnjavanjem}

Budući da je habsburški Dvor zahtijevao „brže“ rezultate i hitnu reformu administrativno-ekonomskog sustava, u ovom slučaju nije bilo dovoljno podukom usmjeriti i senzibilizirati seljaštvo za privrednu problematiku (što je moglo potrajati i generacijama), već se pristupilo i zakonskom uređenju te provedbi željene politike na temelju sustava nadzora i kazne. Zakonska uređenja i reforme, kao i sâm sustav nadzora i kazne, mogu se pratiti od doba vladavine Marije Terezije sredinom 18. stoljeća do razvojačenja Vojne krajine u drugoj polovini 19. stoljeća. Počevši od terezijanskih urbara i redova (za Slavonsku vojnu krajinu najvažniji je svakako „Šumski red“ Marije Terezije iz 1755. godine glede odnosa društva prema šumskim resursima), preko jozefinskih kantonalnih reformi vojnokrajiškog sustava do reakcionarne politike tijekom vladavine Franje I. Austrijskog, uprava i provedba reformi bile su obilježene izrazito centralističkim tendencijama habsburškog Dvora oko uređivanja slavonskog društva i okoliša prema vlastitim nahođenjima i iskustvima stečenima u upravljanju austrijskim nasljednim zemljama.

U duhu već spomenutih tiskanih savjetnika o gospodarsko-društvenim pitanjima, naročito onih vezanih za agrarnu proizvodnju i uređenje, nastaju zakoni, uredbe i urbari koji nastoje slijediti suvremene tendencije obilježene prosvjetiteljskim idejama, industrijskom revolucijom i počecima razvoja moderne znanosti u Europi. Kao najslikovitiji prikaz obujma reformi mogu se ponovno uzeti uredbe vezane za slavonske vojnokrajiške šume, poput npr. Zakona o lovstvu, ${ }^{19}$ raznih uredbi o očuvanju šuma od ilegalne sječe, ispaše stoke i požara, ${ }^{20}$ određivanja točnih cijena usluga i materijala prikazanih po vrijednosti, ${ }^{21}$ ali i opisa službe propisanog bontona šumarskih službenika jer se pokušao uvesti birokratizirani sustav vođen odgovornim i pedantnim činovnicima koji su svoje izvještaje i zadatke morali izvršavati u točno određenim rokovima, no moglo se očekivati da će takav sustav biti teško provesti bez problema i da je korupciju ili nemarnost pri poslu u činovničkim slojevima gotovo nemoguće iskorijeniti, što pokazuju i primjeri mnogobrojnih žalbi na kašnjenje ili neispravnost šumarskih izvještaja, kao i na primjere lošeg vođenja i uređenja državnih šuma u Slavonskoj vojnoj krajini. ${ }^{22}$

Vojnokrajiški je narod vrlo sporo prihvaćao takva ograničenja, naročito ona strožeg karaktera jozefinskih kantonalnih reformi, koja su se nekad u potpunosti sukobljavala s interesima i načinom života lokalnog stanovništva. U povijesti Hrvatsko-slavonske vojne krajine dolazilo je do ustanaka krajišnikâ (npr. bune i ustanci 1658., 1666., 1746.,

19 Lov je „Šumskim redom“ Marije Terezije zabranjen svima u Slavonskoj vojnoj krajini (dotada su lovna prava mogla biti zakupljena), no uskoro je bilo dopušteno loviti časnicima i podčasnicima, dok je običnom krajišniku dozvolu za lov potvrdio tek Josip II. u svojim „Šumskim uredbama“ 1787. godine. Usp. Kosović, "Red i instrukcija“, 150.

20 Hrvatski državni arhiv (dalje: HDA), HR-HDA 451 (Satnija u Babinoj Gredi), Opći spisi (1782.-1802.), kut. 14, Uredba o Ugasenja Pogora (10. prosinca 1782.).

21 Kosović, "Red i instrukcija“, 141-143.

22 HDA, HR-HDA 430 (Slavonska Generalkomanda), Protoccolum in Oeconomicis, knj. 73. Upis za 2. Sjednicu 6. siječnja 1775. godine (Izjava šumskog ophodnika Mascheka od 30. prosinca 1774. o kašnjenju šumarskih izvještaja iz Brodske i Gradiške pukovnije); Franz Vaniček, Specialgeschichte der Militärgrenze, aus Originalquellen und Quellenwerken geschöpft, IV, Wien 1875, 282-283. 
1755. i dr.) koji su zahtijevali poštovanje određenih tradicionalnih prava koja su im bila dodijeljena jer su sad ta ista prava bila podložna reformama i novim tumačenjima. Zbog toga je postojao određen strah među krajiškim stanovništvom zbog potpunoga gubitka egzistencijalnih potrepština i njihova dotadašnjeg načina života. Primjerice, jedna od točaka koju jezeranski knez i porkulab (zapovjednik kaštela) Mate Sertić izlaže pobunjenim krajišnicima tijekom Brinjsko-ličkog ustanka protiv Hildburghausenovih reformi i militarizacije Vojne krajine 1746. godine jest ta da će im vlasti sad potpuno zabraniti sječu drva, koja im je "glavni izvor prehrane“, iako se radilo samo o ograničavanju i sprečavanju "divlje“, nepropisne i nekontrolirane sječe šuma. ${ }^{23}$ Zbog spomenutih buna i sporijeg uvođenja željenih reformi, habsburški Dvor bio je primoran iskoristiti drugu metodu socijalnog discipliniranja - nadzor i kaznu. Uvid u metodu i mnoge zanimljive primjere najbolje nam daje svakodnevica Slavonske vojne krajine, zapisana i sačuvana u Zapovidima Babogredske kompanije 1823.-1824. ${ }^{24}$, a uvod u problematiku donosi sljedeći citat:

Tokom cijelog 18. stoljeća, unutar i izvan sudbenog aparata, u svakodnevnoj kaznenoj praksi, kao i u kritici institucija, oblikuje se nova strategija u izvršavanju kaznene vlasti (...): da se kažnjavanje i represija nad bezakonjem pretvore u redovnu funkciju, koekstenzivnu s društvom; da se ne kažnjava manje, nego bolje; da se kažnjava možda i ublaženom strogošću, ali uz veću univerzalnost i nužnost; da se kaznena moć dublje ucijepi u društveno tijelo.

Stjecaj okolnosti u kojemu se rodila reforma nije, dakle, posljedica novog senzibiliteta, već drugačije politike prema nezakonitom ponašanju. ${ }^{25}$

Ovim riječima francuski filozof, sociolog i povjesničar Michel Foucault daje uvid u promjenu paradigme mehanizama prisile i održavanja institucija reda i moći koja se javlja u „prosvjetiteljskoj Europi“ 18. stoljeća, kada se metoda mučenja zamjenjuje, odnosno pokušava zamijeniti metodom kazne. Babogredska kompanija i njezina svakodnevica u ovom makrohistorijskom aspektu mogu se promatrati kao malen dio vojnog mehanizma, možda i najvažnijeg mehanizma društvenog poretka glede održavanja moći i reda, koji zbog svoje važne uloge treba služiti kao primjer društvu, odnosno kao ogledni obrazac prihvaćenog ponašanja i socijalne discipline koja se očekuje od institucija vlasti.

Nakon smrtne kazne jedna od najtežih tjelesnih kazni za muškarca u Slavonskoj vojnoj krajini bila je špalir („,trčanje kroz šibe“) ${ }^{26}$. Optuženi bi morao hodati ili trčati između dvaju redova poredanih vojnika naoružanih batinama, štapovima ili u ranijim razdobljima čak i kopljima, koji bi ga potom udarali. O težini prijestupa ovisilo je koliko bi puta optuženik morao proći kroz špalir te koliki bi bio ukupan broj ljudi u njemu. Tako, primjerice, najstroži primjer špalira u Zapovidima nalazimo datuma 10. studenoga 1824. godine, kada su kažnjena dvojica graničara zbog bijega iz pritvora i krađe te treći graničar zbog pomoći u krađi, prva dvojica po 10 puta „naprijed-nazad“ kroz špalir od 300 ljudi, dok je treći pro-

23 Željko Holjevac, Brinjsko-lički ustanak 1746. godine, Samobor 2004, 63.

${ }^{24}$ Zapovidi Babogredske kompanije 1823.-1824. godine (ur. Drago Roksandić - Luka Jakopčić), Zagreb Babina Greda - Županja 2017.

25 Michel Foucault, Nadzor i kazna: rađanje zatvora (prev. Divina Marion), Zagreb 1994, 82-83.

26 Zapovidi, 141. 
šao s blažom kaznom od "samo" 6 puta kroz špalir od 300 ljudi. ${ }^{27}$ Standardne procedure kažnjavanja blaže od špalira bila su batinanja štapom ili batinom (njemački termin Stock Streiche $)^{28}$ za muškarce, dok je za žene to bilo bičevanje, a za djecu šibanje. ${ }^{29}$ "Kaštigovati“ (u ovom slučaju fizički kažnjavati) moglo se za svaki manji prijestup, no primjećuje se također kako su vojne vlasti u slučaju problema ili neke regulative imale običaj više puta upozoriti na nepravilnosti i moguće kazne ako ne dođe do željenih promjena. Također, ako bi se dogodio kakav prijestup koji bi imao rizik ponavljanja unutar društva, vlasti bi često Zapovidima upozoravale o još strožim kaznama za buduće prekršaje. Primjer bi bila zabrana kupovanja soli iz Bosne (iz Turske) za koju je kazna bila špalir kroz 300 ljudi, uz upozorenje o povećanju kazne i kroz prisilni rad. ${ }^{30}$

Mehanizam prisile na graničara bio je izrazito strog i autoritaran; gotovo da i nije dopuštao privatni život bez nadzora. Ljudi su mogli biti kažnjeni zbog neurednosti uniforme ili držanja oružja u lošem stanju, nepojavljivanja ili kašnjenja na patrolne dužnosti i stražu, nebrige oko marve ili loše ograđenosti i obrađenosti vlastitih polja, ali i za nećudoredno ponašanje, igranje kola na svetkovine i blagdane, psovanje i neposluh (što javno, što privatno) ${ }^{31}$, zadržavanje poslije 9 sati navečer u selu ili seoskoj krčmi, nedopuštenu sječu i odvoz drva, nepoštovanje i neodlazak na poziv za rad (primjerice, na izgradnju cesta i putova), kao i za neodržavanje urednosti i higijene vlastitog doma i okućnice. Sâm se pojam kazne pojavljuje više od 300 puta u cijelom rukopisnom tekstu Zapovidi ${ }^{32}$ u kontekstu upozorenja i izvještaja o izvršavanju kazne, što ukazuje na vrlo strog mehanizam prisile i nadzora, ali nam također može dati uvid u karakter društva toga doba i prostora.

Demografsko-gospodarski razvoj, kao i „civilizacijski procesi“ civilne i vojne prirode (urbanistički razvoj, ali i razvoj sustava nadzora i fortifikacija) utječu dalje na promjene unutar društva i okoliša Slavonske vojne krajine. U razdoblju od 1715. do 1738. godine gradi se tvrđava u (Slavonskom) Brodu, čija periodična nadogradnja i popravci sežu sve do 1780 -ih godina. ${ }^{33}$ Osim tvrđave, provodila se i izgradnja čardaka (stražarnica) duž lijeve obale rijeke Save te je početkom 18. stoljeća zabilježeno oko 88 čardaka na potezu od Jasenovca do Morovića, da bi do doba Josipa II. (1780. - 1790.) bilo ukupno 245

27 Isto, 122. (Granicsary Albert Stojanovich, Matto Wukovich i Gjuro Wukovich iz Babinegrede, jesu po Sudu i oto Albert zbog Kragye i iz Arresta Utecsenja sa 10 puta gore a 10 puta dolle kroz 300 Momaka sa 2 puta Schibe minjajuche, buduch daje on u istoj Godini 2 Stroffa zbog Kragye primio. Matto Wukovich, koije Kragyu ucsinio i iz Arresta utekao, jest kroz 300 Momaka 10 puta gore a 10 puta dolle Kroz Schibe Kashtigovan, Gyuro Wukovich, koije takodjer od ote Kragye Thall imao, sa 6 puta gore a 6 puta dolle Kroz 300 Momaka)

28 Isto, 141.

29 Alexander Buczynski, „Organizacija policije i pravosuđa u Vojnoj krajini“, Povijesni prilozi, 13, 1994, 102.

30 Zapovidi, 100. (Soll Kupovanje iz Turske jest oshtro zabranito, i dosada sa mallom Kashtigom jesu ovi kojisu ufatiti kashtigovany, alli od sad ochese za takovu Fallinku koji samo 20 Stlara] Solli Turske [288] kupi kroz 300 Momaka kroz Schibe a za vishje i na Rabotu na vishje)

31 Isto, 110. (Stipan i Mato Matassovich N. 121 kojisu swoga Stricza progonilli i njega u kuchanskom poslu slushat nehotilly, jesu sa 20 Batina, a Granicsar Xaweria Mihich N. 104 koije stare Medje u Livady swojoj i swojega Komsjie izsiko i pokwario, jest takojer sa 20 St. St. kashtigowan bio, kojese na Znanje daje)

32 Isto, 5.

33 Mirko Marković, Brod: kulturno-povijesna monografija, Slavonski Brod 1994, 117-127. 
čardaka u cijeloj Slavonskoj vojnoj krajini. ${ }^{34} \mathrm{U}$ drugoj polovini 18. stoljeća sela Slavonske vojne krajine bivaju ušorena te se javlja sve veći broj zidanih kuća od opeke, dok istovremeno državne vlasti nastoje ograničiti potrošnju drvene građe u tradicionalnoj gradnji kuća, kao što je, recimo, primjer zabrane upotrebe hrastovih šindri (daske za krov) iz 1776. godine. ${ }^{35}$

Osim stambene i fortifikacijske gradnje, provodila se i izgradnja te održavanje putova, cesta i mostova, a vrlo je važno pri tome naglasiti da se radilo o močvarnom i poplavnom području, gdje bi lokalne ceste i putovi često bili neprohodni, naročito u kišnim mjesecima, što je stvaralo probleme i pri transportu robe, o čemu svjedoči slučaj iz 1772. godine, kada je bilo nemoguće dostaviti 3.000 hvati (oko $10.230 \mathrm{~m}^{3}$ ) drvene građe iz područja vinkovačkih šuma za potrebe utvrde u Petrovaradinu preko Vukovara jer su cesta i šumski putovi između Vinkovaca i Vukovara zbog loših vremenskih uvjeta neprohodni i da nedostaje dovoljno tegleće stoke za transport građe te je građa naposljetku prebačena vodenim putom. ${ }^{36} \mathrm{O}$ utjecaju vremenskih i cestovnih uvjeta na transport drvene građe bilježi i sljedeći izvadak iz Zapovidi, gdje se podsjeća da se izveze drvena građa dok je prohodan put:

Wishje puta jest Zapovid davana, dase Seoskoj Straxi dokje lipa Puta Derva izvezu buduch da otu opomenu mallo hasni, tako od Strane Compagnie zapovidase, da u Petak tojest Prikosutra svaki izvesti mora, i koji neizveze oche oshtro kashtigan bitty. ${ }^{37}$

Zbog toga su vojne vlasti nastojale paziti na izgled i održavanje putova i cesta koliko je god to bilo moguće, barem onog dijela koji je prolazio kroz naselja. ${ }^{38} \mathrm{Nije}$ samo bilo važno vojnim vlastima održavati put i cestu prohodnima i funkcionalnima, ${ }^{39}$ već se pazilo i na izgled i svojevrsnu „javnu higijenu“, što pokazuje sljedeći primjer iz Zapovidi od 9. travnja 1823. godine, gdje se zabranjuje bacanje raznovrsnog otpada na cestu pod prijetnjom oštre kazne:

Vidilose jest, dase mlogi usudjuju na Drum prama Kucha Smet i drugi kojekakvi Gad i Gjubre baczati, kojise usudi odselle takova ucsinit oche oshtro kashtigovan bitti. ${ }^{40}$

Vrlo bitan dio odgovornosti vojnokrajiškog društva u uređivanju svog životnog prostora i okoliša kojemu su vojne vlasti davale određenu pozornost bilo je ograđivanje polja i okućnica drvenim ogradama ili sadnjom „„̌̌ive ograde“, što se može vidjeti i iz Zapovidi. Najbolje su bile žive ograde od glogovine jer je glog rastao gusto i njegovo je trnje odbijalo mogućnost da čovjek ili stoka prođu kroz njega, no koristile su se i druge vrste grmlja, poput obične žutike (lat. Berberis Vulgaris) ili "rakitovine“" (vjerojatno se misli na vrbu ivu,

34 Josip Kljajić, „,Vojnokrajiški čardaci u Slavonsko-srijemskom Posavlju u 18. i 19. stoljeću“, Povijesni prilozi, 22, 2002, 140-148.

35 Sanja Lazanin, Vinkovci i Vukovar na prijelazu 18. u 19. stoljeće: komparativna urbana historija, doktorski rad, Zagreb 2006, 86.

36 HDA, HR-HDA 430 (Slavonska Generalkomanda), Protoccolum in Oeconomicis, knj. 64. Upis za 12. Sjednicu 11. veljače 1772 . godine.

37 Zapovidi, 6.

38 Isto, 46, 49, 50, 60.

39 Isto, 21.

40 Isto, 20. 
lat. Salix Caprae). ${ }^{41}$ Državnim je vlastima sađenje živih ograda bilo važno zbog ograđivanja državnih i privatnih imanja krajišnikâ, kako bi se spriječili i izbjegli budući sporovi oko zemljišta, kao i šteta od nedopuštene ispaše stoke i njezina nenadziranog „slobodnog lutanja" između vrtova, oranica, livada i šuma. Zbog toga su se često organizirale sadnje živih ograda komunalne prirode, odnosno, slično današnjim javnim radovima, krajišnici pojedinih sela morali su ići saditi žive ograde, npr. pored putova i cesta. ${ }^{42} U$ slučaju nepoštovanja zapovijedi, rušenja živih ograda ili uzrokovanjem štete nastale ulaskom stoke unutar zemljišta zbog loše postavljene i zasađene žive ograde (ili u slučaju neodržavane drvene ograde), vojne vlasti prijetile su strogim kaznama i zatvorom. ${ }^{43}$

\section{4. „Društvo i okoliš po državnom uređenju“}

Analizirani primjeri u ovom radu samo su manji dio fenomena socijalnog discipliniranja društva i uređenja okoliša Slavonske vojne krajine 18. i 19. stoljeća te je svakako moguće na temelju dostupne građe izraditi monografska djela posvećena temama društvenog i okolišnog uređenja na ranonovovjekovnom hrvatskom povijesnom prostoru. Ipak je i ovim mikrohistorijskim primjerima moguće dokazati spomenuti proces, kao i dobiti uvid u "zlatni rez" šire slike vojnokrajiškog društva i slavonskog okoliša toga perioda. Upravo ti sitni detalji u zakonodavnom, gospodarskom i upravnom dijelu politike habsburškog Dvora na ovdašnjim prostorima čine srž te politike i odaju njezin karakter koji istovremeno drži do individualne odgovornosti i obveze pojedinca naspram društva te do društvene odgovornosti i obveze prema pojedincu, nastojeći osmisliti strukturu i hijerarhiju koja bi koristila viziji "općeg dobra“. Koliko je to „opće dobro“ gledano iz perspektive državnih vlasti, a koliko iz perspektive podanika, teško je točno procijeniti na ovakvim relativno manjim primjerima, no iako postoji tendencija prema vladarevu razumijevanju i ispunjavanju potreba svojih podanika, ne smije se zapostaviti činjenica da se ipak radi o prosvijećenom apsolutizmu te da svaki impuls reforme i politička odluka naposljetku dolazi "odozgo“, odnosno od osobe vladara.

Politika prosvijećenog apsolutizma habsburške provenijencije na prostoru Slavonske vojne krajine svakako je ostavila traga na slavonskom društvu i okolišu istoga prostora, što pokazuju i analizirani primjeri socijalnog discipliniranja dvjema metodama: stručnom podukom i savjetom ili zakonskim nadzorom i kaznom. lako se može tvrditi kako je i ranije priručnike slične Jablanczyjevu ili Reljkovićevu Kućniku u početku čitao pismeni dio stanovništva, poput raznog plemstva, klera, časništva ili činovništva, razvoj školstva pod državnom jurisdikcijom u terezijansko doba može se uzeti kao početak obrazovanja nižih društvenih slojeva i njihove obuke ili barem otvaranja mogućnosti za njihovo daljnje učenje o agrarnim proizvodnim mehanizmima i usavršavanje. ${ }^{44}$ Ipak, proces obrazovanja i poduke očigledno je djelovao nedovoljno brzo za potrebe državnih vlasti jer se istovre-

41 Jablanczy, Prirucsna knjiga, 179.

42 Zapovidi, 8, 12, 38.

43 Isto, 54, 57, 95.

44 Usp. Ivančica Marković, "Razvoj pučkih škola u Slavonskoj vojnoj krajini tijekom 18. i 19. stoljeća”, Scrinia Slavonica, 11, 2011, 79-96. 
meno javljaju sve stroži zakoni i uredbe, osjeti se sve više proces centralizacije ne samo unutar javne društvene sfere već $i$ unutar privatne svakodnevice na temelju sustavâ nadzora i kazni, koji služe osiguravanju "uspješnosti“ željenih reformi. Ti reformsko-pravni procesi djeluju preko društva i na okoliš Slavonske vojne krajine, gdje, osim spomenutih lokaliziranih primjera, postoje i oni šireg opsega i utjecaja, poput demografskog razvoja, širenja obradivih površina krčenjem šuma i isušivanjem močvara, ${ }^{45}$ uvoza novih i razvoja postojećih poljoprivrednih kultura i načina njihove obrade (npr. krumpir 1770-ih godina) ${ }^{46}$. Navedeni makro- i mikrohistorijski primjeri opisuju zanimljivu paradigmu: umjesto adaptacije okolišnim uvjetima od strane društva (ekocentrizam), okoliš biva adaptiran društvenim uvjetima (antropocentrizam ili sociocentrizam), no u ovom je slučaju bitan i "treći“ posrednik: država, kao vrhovni društveni mehanizam koji nadilazi lokalizirano iskustvo odnosa društva i okoliša te nastoji adaptirati društvo i okoliš svojim ciljevima i potrebama (politocentrizam).

Što se tiče druge metode socijalnog discipliniranja i društvene kontrole nadzorom i kaznom, za istaknute slučajeve i fenomene unutar Babogredske kompanije, koji su opisani i spomenuti u analizi Zapovidi Babogredske kompanije 1823.-1824. godine, prema „fukoovskim“ pravilima kažnjavanja, principijelno bi najvažnija bila dva pravila: pravilo sporednog učinka i pravilo potpune izvjesnosti. Pravilo sporednog učinka zahtijeva najjači učinak i percepciju kazne upravo od onih koji nisu ili neće biti kažnjeni, dok pravilo potpune izvjesnosti nalaže da se svakoj ideji ili želji o zločinu ili prekršaju pridruži pomisao o točno utvrđenoj kazni te njezinim mogućim posljedicama i neugodnostima ${ }^{47}$ Discipliniranje društva i njegova okoliša po spomenutim metodama i obrascima državne vlasti unutar Habsburške Monarhije samo je jedan od pokazatelja modernizacije temeljene na mehanicističkim, strukturalnim i hijerarhijskim konceptima uređenja (srednjoeuropske) civilizacije, koji krajem 19. stoljeća dosežu svoj vrhunac utjecaja na društvo i okoliš Slavonije, a čije se pojedine posljedice i obrasci primjećuju još i danas.

45 Karl Kaser, Slobodan seljak i vojnik: militarizirano društvo 1747.-1881., Zagreb 1997, 104-106.

46 Vaniček, Specialgeschichte der Militärgrenze, aus Originalquellen und Quellenwerken geschöpft, II, Wien 1875, 597-599.

47 Foucault, Nadzor i kazna, 96. 